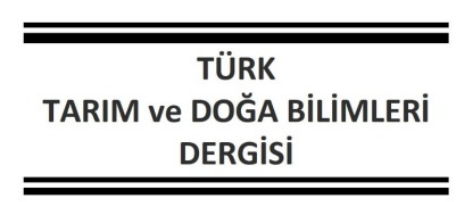

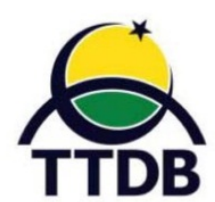

www.dergipark.gov.tr/turkjans

Araştırma Makalesi

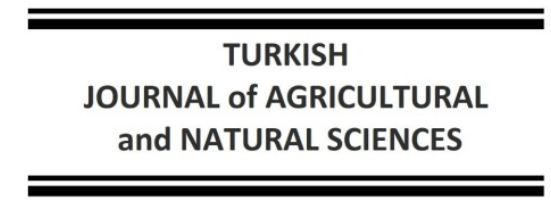

\title{
Formalin ile İnaktive Flavobacterium psychrophilum'un Gökkuşağı Alabalığı (Oncorhynchus mykkiss)'nın Antioksidan Enzimlerine Etkisi
}

\author{
Muammer $\mathrm{KIRICl}^{1}$, Mahinur $\mathrm{KIRICl}^{2}$, Mehmet Reşit TAYSI ${ }^{3,}$, ,Ünal iSPiR ${ }^{4}$
}

\begin{abstract}
${ }^{1}$ Bingöl Üniversitesi, Gıda Tarım ve Hayvancılık Meslek Yüksekokulu, Veterinerlik Bölümü, Bingöl ${ }^{2}$ Bingöl Üniversitesi, Sosyal Bilimler Meslek Yüksekokulu, Mülkiyet Koruma ve Güvenlik Bölümü, Bingöl.

${ }^{3}$ Bingöl Üniversitesi, Ziraat Fakültesi, Su Ürünleri Bölümü, Bingöl.

${ }^{4}$ Malatya Turgut Özal Üniversitesi, Doğanşehir Vahap Küçük MYO, Malatya.

*Sorumlu Yazar: mrtaysi@yahoo.com
\end{abstract}

\section{Geliş Tarihi: 18.12.2020 Düzeltme Geliş Tarihi: 05.03.2021 Kabul Tarihi: 07.04.2021}

\section{$\overline{O ̈ z}$}

Bu çalışmada, formalin ile inaktive edilen Flavobacterium psychrophilum'un yavru gökkuşağı alabalıklarında bazı antioksidan enzim parametrelerinde oluşturduğu değişiklikler incelenmiştir. Yaklaşık $1.0 \mathrm{~g}$ ağırlığında olan gökkuşağı alabalığı yavruları formalin ile inaktive edilmiş 1x108 CFU/ml bakterin ile 30, 60 ve 90 dakika muamele edildi. Balıklar, uygulamadan 21 gün sonra $1 \times 108 \mathrm{CFU} / \mathrm{ml}$ canlı F. psychrophilum ile eprüvasyon yapıldı. On dört gün sonra ise balıklardan alınan örnekler ile malondialdehit (MDA), süperoksit dismutaz, katalaz ve redükte glutatyon aktivitelerindeki değişiklikler incelendi. MDA düzeyinde özelikle 60 ve 90 dak. bakteri uygulanan balıklarda ılımlı pozitif kontrol grubuna göre bir azalış gözlendi. Antioksidan enzim aktivitelerinde de aynı şekilde olumlu yönde bir değişiklik saptandı. Sonuç olarak; formalin ile inaktive edilen bakteri preparatının, canlı F. psychrophilum bakterisi tarafından bozulan oksidan/antioksidan dengesinin düzenlenmesinde etkili olabileceği tespit edilmiştir.

Anahtar kelimeler: Flavobacterium psychrophilum, formalin, gökkuşağı alabalığı, oksidan/antioksidan dengesi.

\section{The Effect of Formalin-Inactivated Flavobacterium psychrophilum on Antioxidant Enzymes of Rainbow Trout (Oncorhynchus mykiss)}

\begin{abstract}
In this study, the changes caused by Flavobacterium psychrophilum inactivated with formalin in some antioxidant enzyme parameters in juvenile rainbow trout were investigated. Rainbow trout juveniles weighing about $1.0 \mathrm{~g}$ were treated with $1 \times 108 \mathrm{CFU} / \mathrm{ml}$ bacterin inactivated with formalin for 30, 60 and 90 minutes. Fish were stimulated with $1 \times 108 \mathrm{CFU} / \mathrm{ml}$ live F. psychrophilum 21 days after application. Fourteen days later, changes in malondialdehyde (MDA), superoxide dismutase, catalase and reduced glutathione activities were investigated with samples taken from fish. A decrease was observed in MDA level especially in fish treated with bacteria for 60 and 90 minutes compared to positive control group. Likewise, a positive change was found in antioxidant enzyme activities. As a result; It has been determined that the bacterial preparation that is inactivated with formalin can be effective in the regulation of the oxidant / antioxidant balance, which is disturbed by the live F. psychrophilum bacteria.
\end{abstract}

Key words: Flavobacterium psychrophilum, formalin, rainbow trout, oxidant / antioxidant balance.

Giriş

Bakteriyel soğuksu hastalığı (Bacterial Cold Water Disease, BCWD) ve/veya Gökkuşağı alabalığı yavru sendromu (Rainbow Trout Fry Syndrome,
RTFS)'na neden olan Flavobacterium psychrophilum Gram-negatif bir bakteri olup Salmonidlerde akut septisemiye neden olmaktadır. F. psychrophilum tüm dünyada özellikle tatlı su 
salmonid yetiştiriciliğinde giderek daha fazla görülmeye başlanmıştır. Fransa (Bernardet ve Kerouault, 1989); Danimarka (Dalsgaard ve Madsen, 2000); Avustralya (Schimidtke ve Carson, 1995); Şili (Bustos ve ark., 1995); Finlandiya (Wiklund ve ark., 1994); Japonya (Wakabayashi ve ark., 1991; Wakabayashi ve ark., 1994); Ingiltere (Austin ve Stobie, 1991; Santos ve ark., 1992) ve USA (Pacha, 1968; Kent ve ark., 1989)'da bu etken tespit edilmiştir. Salmonid balıkların tamamı bu bakteriden etkilenmektedir. Fakat Coho salmon (Oncorhynchus kisutch) ve gökkuşağı alabalığı (Oncorhynchus mykiss)'nda ciddi sorunlar oluşturmaktadır.

Ülkemizin birçok bölgesinde alabalık üretim ve yetiştiriciliği yapılan tesislerde de bu patojenin izolasyonu ve identifikasyonu yapılmıştır (Diler ve ark., 2003, İspir ve ark., 2004; Şeker ve ark., 2006; Kılıç ve ark., 2007; Özer ve ark., 2008; Yıldırım ve Özer, 2010; Özcan ve Sarıeyyüpoğlu, 2014; İspir ve ark., 2016; Ersoy ve ark., 2018; Satıcıoğlu ve ark., 2018; Ekipmen ve ark., 2020; Önalan ve Çevik, 2020).

Kültür balıkçılığında bakteriyel enfeksiyonları kontrol etmenin en etkili yolu olarak bilinen aşılama günümüzde rutin balıkçılık faaliyeti olarak kullanılmaya başlanmıştır. Artan balık yetiştiriciliği ile birlikte mikrobiyal etkenlerin vücutta oluşturduğu olumsuzlukları azalmak için yeni aşı hazırlama teknikleri ile aşılar hazırlanmaktadır. Ancak bu bakteriye karşı bugüne kadar aşı hazırlamak için çeşitli araştırmalar yapılmış olmasına rağmen hala etkili ve lisanslı bir aşı geliştirilememiştir. Bu, bakterinin bölgeden bölgeye farklılık gösterebilen antijenik yapısından kaynaklandığı düşünülmektedir. Balık yetiştiriciliğinde bazı enfeksiyonlara karşı etkenin formalin ile inaktive edilerek uygulanmasında olumlu sonuçların alındığı bilinmektedir (Gutierrez ve Miyazaki, 1994; Ispir ve ark., 2009; Huang ve ark., 2014; Nguyen ve ark., 2017; Pulpipat ve ark., 2020) Buna karşın F. psychrophilum'a karşı formalin ile inaktive edilen bakterinin immunizasyon sağlamadığı gösterilmiştir (Kırıcı ve ark., 2014). Ülkemizde 1990'lı yıllardan sonra görülmeye başlanan ve hızla tüm yurt çapında bulunan balık üretim tesislerine yayılan, işletmelerde ağır mortalite nedeniyle büyük ekonomik kayıplar oluşturan F. psychrophilum etkenine karşı farklı metotlarla inaktive edilerek hazırlanan preperatların fizyolojik mekanizmalarda oluşturduğu etkilerin bilinmesi, bu bakteri ile daha etkili mücadelenin yapılabilmesine imkân sağlayacaktır. Bu bağlamda formalin ile inaktive bakterinin nispi hayatta kalma oranını artırmadığı (Kırıcı ve ark., 2014) bilinse dahi biyokimyasal parametrelerdeki etkilerinin bilinmesi önemli bir katkı sunacaktır. Bu nedenle bu çalışmada formalin ile inaktive edilen F. psychrophilum'un balıkların lipit peroksidasyon ve antioksidan yapılarındaki etkilerinin araştırılması amaçlanmıştır.

\section{Materyal ve Metot}

Denemede daha önceden gökkuşağı alabalığı yavru sendromunun görülmediği ticari bir balık üretim tesisinden elde edilen ağırlığı yaklaşık $1.0 \mathrm{~g}$ olan gökkuşağı alabalığı yavruları kullanıldı. Balıklar havalandırmanın düzenli olarak yapıldığı, su sıcaklığının $15 \pm 0.5^{\circ} \mathrm{C}$, çözünmüş oksijen düzeyinin $6 \pm 0.9 \mathrm{mg} / \mathrm{L}$ olduğu tanklara yerleştirildi ve yeni yerlerine alışmaları ve yem alımlarının düzenlenmesi için 2 hafta adaptasyon süresi uygulandı. Tüm deneme boyunca balıklar günde iki defa ad libitum olarak ticari bir alabalık yemi ile beslendi. Adaptasyon süresi sırasında balıklardan rastgele örneklemeler yapılarak $\mathrm{F}$. psychrophilum'un varlığı araştırıldı ve sonuçların negatif olduğu tespit edildi.

Çalışmada, daha önceden bir gökkuşağı alabalığı kuluçkahanesindeki balıklardan izole edilen F. psychrophilum suşu (İspir ve ark., 2013) kullanıldı. Bakterinin formalin ile inaktivasyonu, Kırıcı ve ark. (2014)'nın bildirdiği metoda göre yapıldı. TYES-B'de $15^{\circ} \mathrm{C}^{\prime}$ de kültürü yapılarak gençleştirilen bakteri kültürüne son konsantrasyon \%3 olacak şekilde formaldehit ilave edildi. Bakterinin inaktivitesi TYES agara ekim yapılarak kontrol edildi. Üreme göstermeyen bakteri kültürleri 10000 rpm'de 20 dakika santrifüj edildi ve $1 \times 108 \mathrm{CFU} / \mathrm{ml}$ olacak şekilde ayarlandı.

Deneylere başlamadan önce balıklar her tankta 50 adet olacak şekilde 5 gruba ayrıldı. Gruplar; Grup I: Uygulama yapılmayan balıklardan oluşan kontrol grubunu, Grup II: F. psychrophilum uygulanan grup (1x108 CFU/mL) Grup III: 30 dakika formalinde inaktive edilen $F$. psychrophilum uygulanan grup, Grup IV: 60 dakika formalinde inaktive edilen F. psychrophilum uygulanan grup, Grup V: 90 dakika formalinde inaktive edilen F. psychrophilum uygulanan grup, olarak oluşturuldu. İmmunizasyondan 21 gün sonra deney ve kontrol grubu balıkları, $1 \times 108 \mathrm{CFU} / \mathrm{mL}$ olacak şekilde hazırlanan canlı F. psychrophilum ile 2 saat için maruz bırakıldı. Bu işlemden sonra 14 . gün sonunda her gruptan rastgele 20 balık alınarak 50 ppm benzokain ile anestezi edildi ve sıvı azot kullanılarak homojenleştirildi ve $50 \mathrm{mM} \mathrm{KH2P04}$ tamponu ( $\mathrm{pH}$ 7.4) içerisinde süspanse edildi. Homojenat, 27.000 g'de 60 dakika santrifüj edildi ve süpernatant alınarak enzim aktivitelerinin belirlenmesinde kullanılmak üzere $-20{ }^{\circ} C^{\prime}$ de saklandı (Beutler, 1975). 
Alınan örneklerin MDA düzeylerinde meydana gelen değişimler Placer ve ark. (1966)'den modifiye edilen yönteme göre spektrofotometrik olarak ölçüldü. Dokulardaki CAT aktivitesi Aebi (1974) ve SOD düzeyi Sun ve ark., (1988)'ne göre tayin edildi. Protein tayini ise Lowry ve ark., (1951)' nin bildirdiği metoda göre belirlendi. GR düzeyi Carlberg ve Mannervik (1975) tarafından bildirilen metoda göre yapıldı.

Veriler ortalama \pm standart hata olarak ifade edildi. Bir istatistik programı yardımıyla (SPSS 17.0) tek yönlü ANOVA uygulaması sonrasında kontrol ve deney grupları arasındaki anlamlı farkın olup olmadığını belirlemek için Duncan testi kullanıldı. $p<0.05$ değeri istatistiksel olarak anlamlı kabul edildi.

\section{Bulgular}

İnaktive bakterinin ve canlı bakteri ile muamele edilen balıklarda F. psychrophilum ile karakterize enfeksiyon semptomları gözlenmemiştir. Tüm çalışma boyunca deneysel gruplarda balık ölümü gerçekleşmemiştir.

$\mathrm{Bu}$ çalışmada Lipid peroksidasyon (MDA) ve antioksidan savunma seviyeleri enzimlerin (CAT, SOD ve GR) düzeyleri Şekil 1-4'de verilmiştir. Inaktive bakteri ile 60 ve 90 dakika uygulaması yapılarak immunize edilmiş gökkuşağı alabalığında MDA seviyeleri sadece canlı bakteri uygulanmış pozitif kontrol grubu balıklarına göre önemli ölçüde azalmıştır $(p<0.05)$ (Şekil 1). Deney gruplarında ortalama MDA değerleri kontrol grubuna göre sırasıyla $53 \pm 2.94,86 \pm 4.03,91 \pm 5.27,74 \pm 4.60$ ve $71 \pm 4.11 \mathrm{~nm} / \mathrm{mg}$ proteindir.

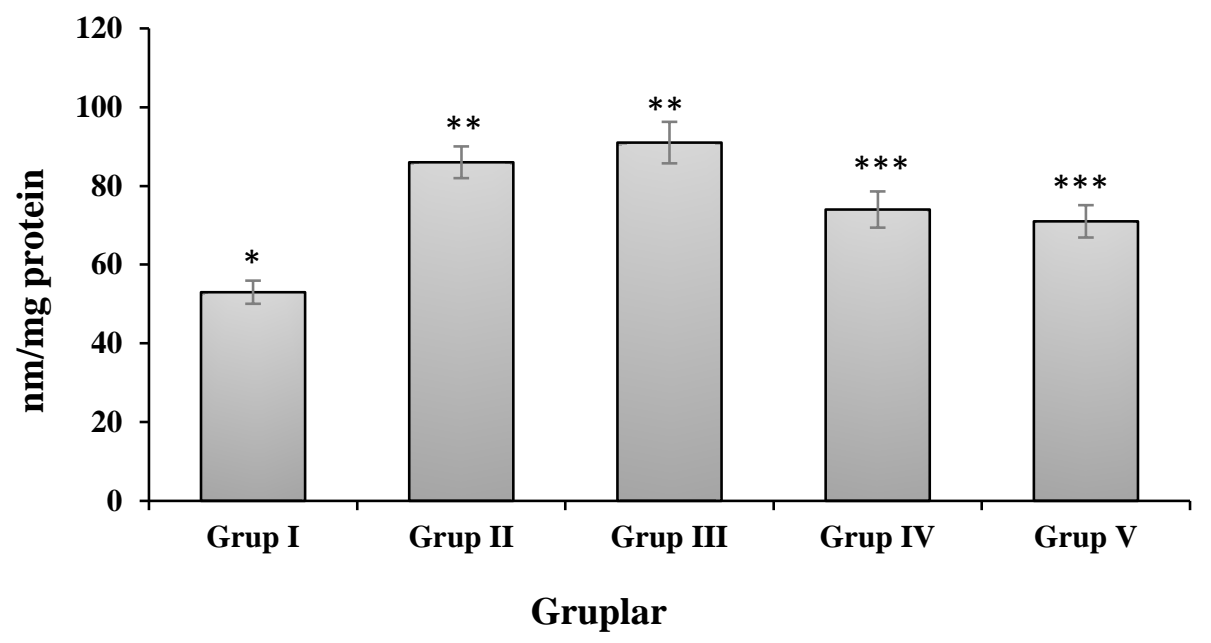

Şekil 1. F. psychrophilum ve formalinle inaktive edilen F. psychrophilum uygulanan alabalık lipid peroksidasyon seviyeleri (MDA).

(Grup I: hiçbir şey uygulanmayan kontrol grubunu, Grup II: F. psychrophilum uygulanan grup, Grup III: 30 dakika formalinde inaktive edilen $F$. psychrophilum uygulanan grup, Grup IV: 60 dakika formalinde inaktive edilen $F$. psychrophilum uygulanan grup, Grup V: 90 dakika formalinde inaktive edilen $F$. psychrophilum uygulanan grup). Veriler, Aritmetik ortalama \pm Standart hata şeklinde verilmiştir $(\mathrm{n}=20) . *, *, * * *$ gruplar arasındaki istatistiksel farklılı̆̆ı göstermektedir $(\mathrm{p}<0.05)$.

Inaktive bakterin ile immunizasyon sağlanmış ve canlı F. psychrophilum ile maruz bırakılmış balıklarda SOD aktivitelerindeki farklılıklar ve bakterinin farklı sürelerde uygulanması sonrasında ki etkileri Şekil 2'de gösterilmiştir. Formalin ile inaktive bakterinin uygulama süresine göre balıkların SOD aktivitesi gruplar arasında sırasıyla $21 \pm 2.86,10 \pm 1.12,8 \pm$ $1.06,12 \pm 1.75$ ve $14 \pm 1.64 \mathrm{U} / \mathrm{mg}$ protein bulundu. Kontrol balıklarında ise SOD aktivitesinde önemli bir değişiklik ( $p>0.05$ ) gözlenmedi. 


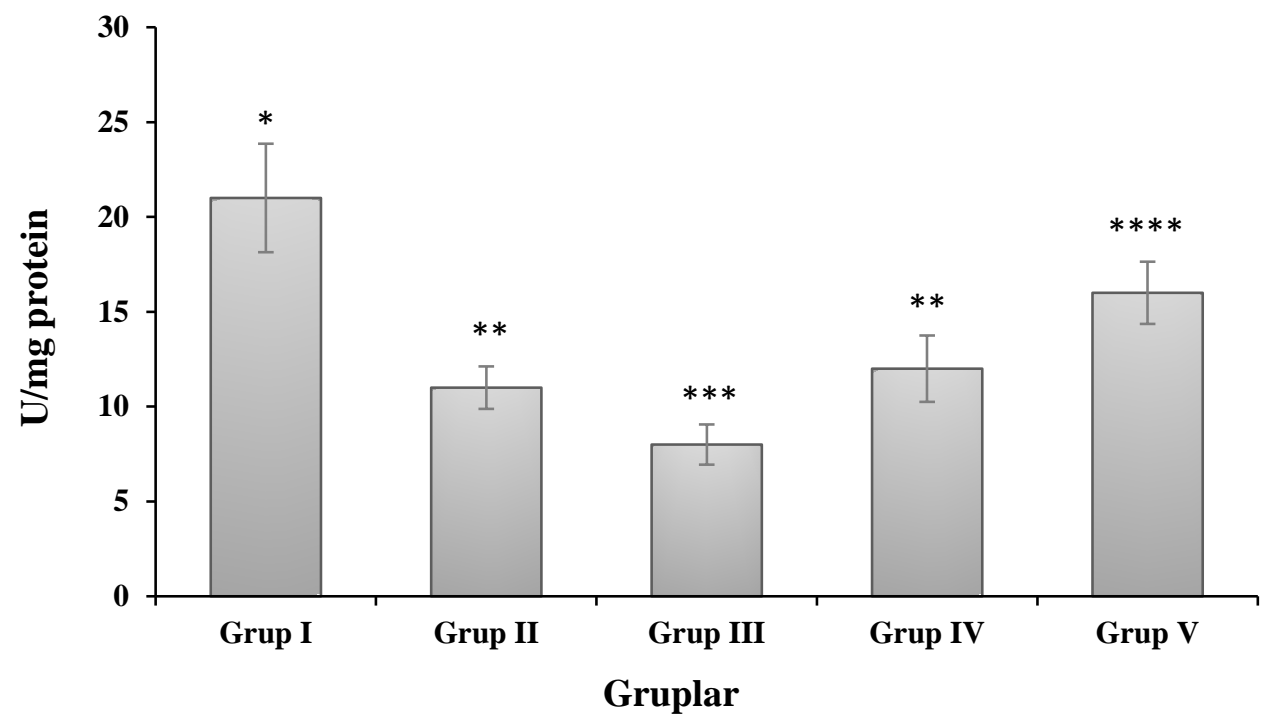

Şekil 2. F. psychrophilum uygulanan ve formalinle inaktive edilen F. psychrophilum ile 30, 60 ve 90 dakika banyo sonrası alabalık süperoksit dizmutaz aktiviteleri (SOD).

(Grup I: hiçbir şey uygulanmayan kontrol grubunu, Grup II: F. psychrophilum uygulanan grup, Grup III: 30 dakika formalinde inaktive edilen $F$. psychrophilum uygulanan grup, Grup IV: 60 dakika formalinde inaktive edilen $F$. psychrophilum uygulanan grup, Grup V: 90 dakika formalinde inaktive edilen $F$. psychrophilum uygulanan grup). Veriler, Aritmetik ortalama \pm Standart hata şeklinde verilmiştir $(\mathrm{n}=20){ }^{*, * * * * *, * * * *}$ gruplar arasındaki istatistiksel farklıı̆ı̆ı göstermektedir $(p<0.05)$.

İmmunize balıklarda canlı bakterin uygulanmasından sonra CAT aktivitelerinde yükselmeler gözlendi. Yükselme oranı en fazla 60 dakika formalinde inaktive edilen F. psychrophilum uygulanan grupta kontrol grubuna göre önemli ölçüde arttı, diğer gruplarda ise sırasıyla $121 \pm 9.26$, $86 \pm 5.22,89 \pm 4.86,108 \pm 6.93$ ve $109 \pm 7.02 \mathrm{U} / \mathrm{mg}$ protein bulundu. Kontrol grubunda CAT aktivitesinde önemli bir değişiklik $\quad(p>0.05)$ gözlenmedi (Şekil 3).

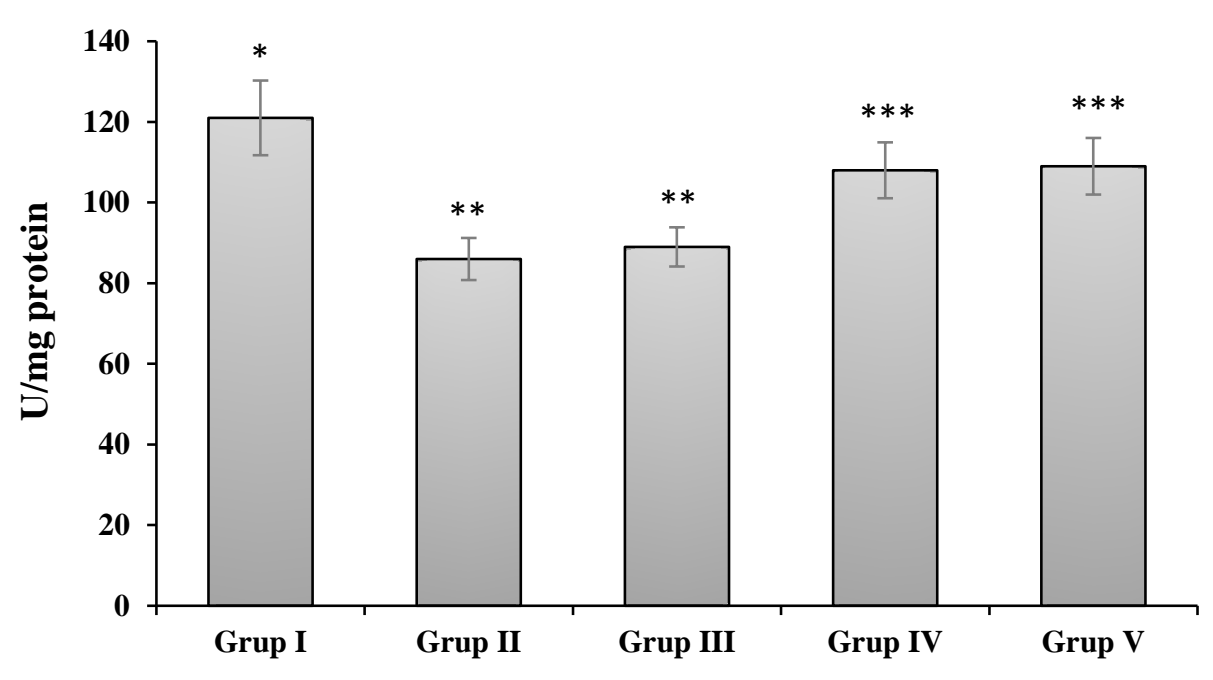

Gruplar

Şekil 3. F. psychrophilum uygulanan ve formalinle inaktive edilen F. psychrophilum ile 30, 60 ve 90 dakika banyo sonrası alabalık katalaz aktiviteleri (CAT).

(Grup I: hiçbir şey uygulanmayan kontrol grubunu, Grup II: F. psychrophilum uygulanan grup, Grup III: 30 dakika formalinde inaktive edilen F. psychrophilum uygulanan grup, Grup IV: 60 dakika formalinde 
inaktive edilen F. psychrophilum uygulanan grup, Grup V: 90 dakika formalinde inaktive edilen $F$. psychrophilum uygulanan grup). Veriler, Aritmetik ortalama \pm Standart hata şeklinde verilmiştir $(\mathrm{n}=$ 20). $*, * *, * * *$ gruplar arasındaki istatistiksel farklılığı göstermektedir $(\mathrm{p}<0.05)$.

GR aktivitelerindeki değişiklikler Şekil 4'te gösterilmektedir. Kontrol grubu ile deneme gruplarının GR aktiviteleri karşılaştırıldığında aralarındaki azalış istatistiki olarak önemlidir.

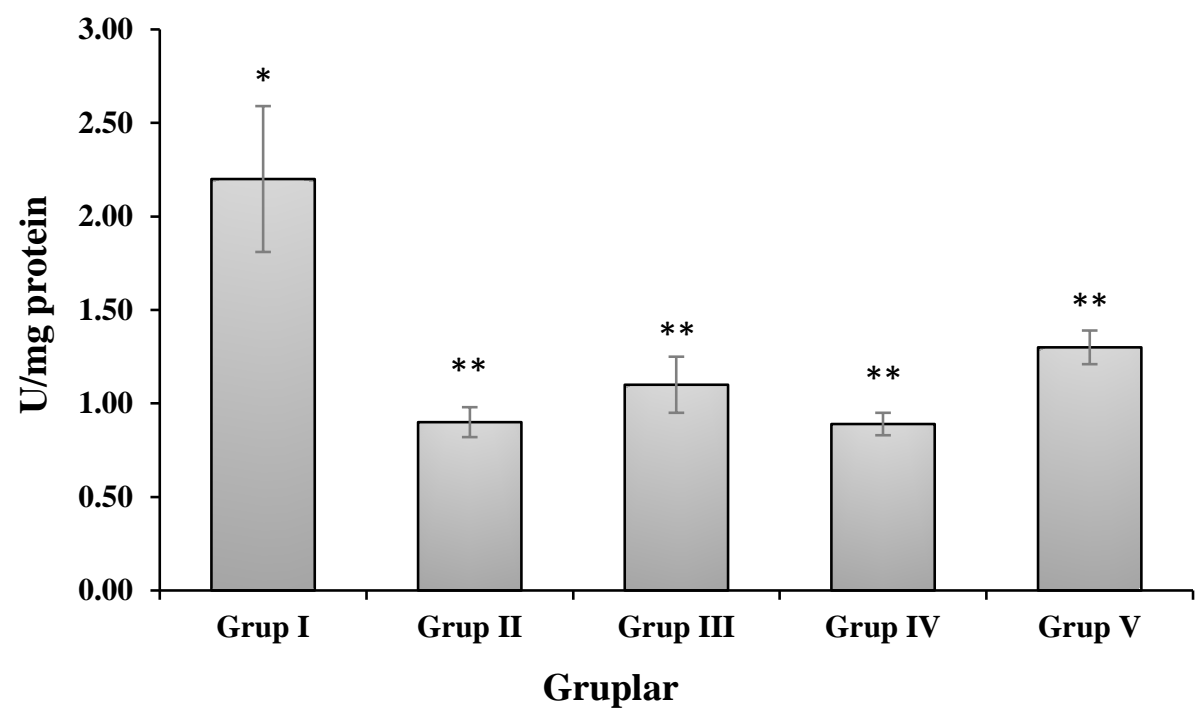

Ayrıca bakteri uygulanan grup ile 90 dakika inaktive bakteri uygulanan grup arasındaki artışın önemli olduğu tespit edilmiştir $(p<0.05)$

Şekil 4. F. psychrophilum uygulanan ve formalinle inaktive edilen F. psychrophilum ile 30, 60 ve 90 dakika banyo sonrası alabalık glutatyon redüktaz aktiviteleri (GR).

(Grup I: hiçbir şey uygulanmayan kontrol grubunu, Grup II: F. psychrophilum uygulanan grup, Grup III: 30 dakika formalinde inaktive edilen $F$. psychrophilum uygulanan grup, Grup IV: 60 dakika formalinde inaktive edilen F. psychrophilum uygulanan grup, Grup V: 90 dakika formalinde inaktive edilen $F$. psychrophilum uygulanan grup). Veriler, Aritmetik ortalama \pm Standart hata şeklinde verilmiştir $(\mathrm{n}=$ 20). ${ }^{* * *, * * *}$ gruplar arasındaki istatistiksel farklılı̆ı göstermektedir $(p<0.05)$.

\section{Tartışma}

Enfeksiyonların, toksik maddelerin, aşılamanın ve yaşın oksidatif strese neden olabileceği ve sonrasında da oksidatif hasar oluşturabileceği bildirilmiştir (Pryor, 1986). Oksidatif stres; antioksidanların tükenmesi veya reaktif oksijen türlerinin (ROS) aşırı birikmesinden kaynaklanabileceği gibi her ikisine bağlı olarak ortaya çıkabilir (Yang ve ark., 2010). Oksidatif stresin oluşması biyokimyasal ve fizyolojik işlevlerde değişikliklere neden olabilir (Halliwell, 1994). Hücrede meydana gelen bu serbest radikallerin bu zararlı etkilerini etkisiz hale getirmek için enzimatik ve enzimatik olmayan antioksidan savunma mekanizmaları geliştirilmiştir (Sies, 1991).

Bu çalışmada, formalin ile inaktive bakteri hücresi ile immunize sağlanmış gökkuşağı alabalığı yavrularında oksidatif stresin indüksiyonu, en yaygın kullanılan belirteçler kullanılarak analiz edildi. Çalışma sonuçları, F. psychrophilum'a karşı formalin ile inaktive bakterinin verildiği gökkuşağı alabalığının tüm vücut dokusundaki oksidatif stres profilinde uygulama sonrası bir değişiklik olduğunu göstermektedir. Farklı hastalık etkenlerinin gökkuşağı alabalıklarında stres kaynağı oluşturduğu ve ilişkili gen ekspresyon seviyelerinde de stres ve immünite seviyelerinde artış olduğu bildirilmiştir (Önalan, 2019).

Patojenik bir mikrorganizma; sindirim, absorpsiyon ve detoksifikasyon gibi bazı spesifik fonksiyonlarla yakından ilişkili olan membran lipid peroksidasyonunu indüklemektedir (Pan ve ark., 2003). Malondialdehit (MDA), lipid peroksidasyonunun son ürünlerinden biridir. Reaktif oksijen türlerinin fazlası ile çeşitli hastalıklarda MDA içeriği arttığı için serbest radikal hasarı ile pek çok ilişki gözlenmiştir (Rahal ve ark., 2014). MDA, hücre zarlarında yıkım ve hasarın en önemli nedeni olarak gösterilmiştir. Bu hasar, hücre zarlarının çoklu doymamış yağ asitlerinin 
parçalanması ve bunun sonucunda zar bütünlüğünün kopmasından kaynaklanmaktadır (García ve ark., 1997). Bu nedenle, enfeksiyondan kısa bir süre sonra fizyolojik hasar ya da ölüm görülmektedir. Yani MDA, oksidatif hasarın bir göstergesidir. Bu çalışmada; MDA sonuçlarının, hiçbir uygulama yapılmayan kontrol grubuna göre immunize balıkların dokusunda arttığı gözlendi $(p<0.05)$. Buna rağmen canlı bakteri uygulanan gruptaki balıklardan elde edilen MDA düzeyinden ise daha düşük olduğu tespit edildi $(p<0.05)$.

Oksidatif stres, reaktif oksijen türlerinin üretimi ve düzenlenmesi arasındaki bir dengesizlik olarak tanımlanmaktadır (Yang ve ark., 2010). Oksidatif hasar, antioksidan savunma sisteminin ROS'un uzaklaştırılmasındaki başarısızlığı ile lipidler, proteinler veya DNA gibi biyomoleküllerin hasar görmesine yol açması ile ilgilidir (Mişe Yonar, 2013). Bu çalışmanın sonuçları, SOD, CAT ve GR aktivitelerinin, immunizasyon sonrasında kontrol grubuna göre etkilendiğini göstermektedir. Bu değişiklikler oksidatif stresin varlığını göstermektedir.

CAT, ROS gideriminde yer alan birincil antioksidan enzimlerden biridir (Downs ve ark., 2001). SOD'nin katalitik reaksiyonu ile oluşan hidrojen peroksit (H2O2), hem reaktif bir oksijen formu hem de normal bir hücresel metaboliti CAT tarafından detoksifiye edilir. H2O2 katabolizması, süperoksit radikal anyonunun oluşumuna yol açar (Sinclair, 1993). Bu çalışmada, kontrol grubu ile deneme gruplarının CAT aktiviteleri arasındaki azalış istatistiki olarak önemli olduğu görüldü. Ayrıca bakteri grubu ile 30 dakika inaktive bakteri uygulanan grup arasındaki fark önemli değil iken, bakteri grubu ile 60 ve 90 dakika inaktive bakteri uygulanan gruplar arasındaki farkın önemli olduğu tespit edildi $(p<0.05)$. Bu çalışmanın verileri, bakterin ile immunize balıklarda CAT aktivitesinin canlı bakteri uygulanan gruba göre artış göstermesi CAT'ın artan aktivitesi, immunizasyon ile vücutta serbest serbest radikal üretiminde bir azalmanın olabileceğinden kaynaklanabilir. Xia ve ark. (2017), A. hydrophila ile enfekte balıklarda kontrol balıklarına kıyasla CAT aktivitesinin önemli ölçüde azaldığını bildirmiştir. SOD, süperoksidin hidrojen peroksite parçalanmasını katalize eden, önemli bir antioksidan rol oynayan ve aerobik organizmalardaki Süperoksit radikallerinin toksik etkilerine karşı ilk savunmayı oluşturan bir metaloenzimdir (Cheeseman ve Slater, 1992). Bu çalışmada canlı bakteri verilen grupta SOD aktivitesinin azalması, bu enzimin sadece aşırı ROS'un uzaklaştırılmasında değil aynı zamanda bağışıklı sisteminde de rol oynadığı gösteren önemli bir olgudur. Xia ve ark. (2017), A. hydrophila ile infekte Megalobrama amblycephala'da SOD aktivitesinin önemli ölçüde azaldığını bulmuşlardır. Bakteriyal etkenlerle enfekte balıklarla anti-oksidatif savunmaya ilişkin yapılan çalışmalarda, SOD ve CAT aktivitelerine ilişkin farklı sonuçların alındığı bildirilmektedir. ElSayed ve ark., (2019) A. hydrophila ile enfekte Nile tilapia; Tkachenko ve ark., (2014) furunkluzis ile enfekte gökkuşağı alabalığında SOD ve CAT aktivitesinin arttığını bildirmişlerdir. Gökkuşağı alabalıklarında Yersinia ruckeri ile enfeksiyon oluşturulan bir çalışmada aşılamanın yapıldığı grupta SOD aktivitesinin kontrol grubuna göre yüksek olduğu bulunmuştur (Tkachenko ve ark., 2017). Bu çalışmalar da bizim sonuçlarımızdan farklı veriler elde edilmesinin nedeni, balık ve bakteri türünün farklılığından kaynaklandığı düşünülmektedir. Bu çalışmada elde edilen veriler canlı bakteri verilen gruptaki balıklarda, kontrol grubundakilere göre daha düşük seviyelerde CAT ve SOD aktivitelerine sahip olduğunu gösterdi. Bu grup balıklar ile immunize gruplardaki balıkları arasında antioksidan savunma durumunda oluşan farkların istatistiki olarak farklı olduğu tespit edildi. Ayrıca, çalışmada canlı bakteri uygulanan grupta MDA' nın artışı hücre zarında oksidatif hasarın oluştuğunu göstermektedir.

GR, hücresel antioksidan koruma ve metabolik yolların uyum süreçlerinde önemli bir rol oynar (Cazenave ve ark., 2006). NADPH'ye bağlı bir reaksiyonda glutatyon disülfidin indirgenmiş glutatyona indirgenmesini katalize eder. Bu çalışmada immunize balıklarda, canlı bakteri uygulanan gruba göre GR aktivitesinde istatistiki olarak anlamlı bir artış belirlenmiştir $(p<0.05)$. Tkachenko ve ark., (2017) Y. ruckeri'ye karşı aşılanan gökkuşağı alabalıklarında GR aktivitesinde canlı bakteri verilen kontrol grubuna göre daha yüksek olduğunu bulmuşlardır.

Bu çalışmada, F. psychrophilum'a karşı inaktive bakteri ile immunizasyondan sonra gökkuşağı alabalığında lipid peroksidasyon ve antioksidan durumun analizi yoluyla oksidatif stres belirteçlerinin belirlenmesiyle gökkuşağı alabalığı yavrularında immunizasyon sırasında tetiklenen mekanizmalara ışık tutacağı açıktır. Çalışmadaki bulgular, immunize gökkuşağı alabalıktaki biyokimyasal değişikliklerin anlaşılması, immunizasyonda meydana gelen karmaşık fizyolojik olayların açıklanmasında, aynı zamanda enfeksiyona karşı balık sağlığını artırmada yeni stratejilerin üretilmesinde ve iyi yetiştiricilik uygulamalarında sonraki çalışmalarda önemli çıkarımlara sahip olacaktır.

Çıkar Çatışması Beyanı: Makale yazarları aralarında herhangi bir çıkar çatışması olmadığını beyan ederler. 
Araştırmacıların Katkı Oranı Beyan Özeti: Yazarlar makaleye eşit oranda katkı sağlamış olduklarını beyan ederler.

\section{Kaynaklar}

Aebi, H. 1974. Catalase. In H.U. Bergmeyer, (Ed.), Methods in enzymatic analysis. New York, NY: Academic Press. p. 673-680, ISBN 9780323161374

Austin, B., Stobie, M. 1991. Recovery of yellowpigmented bacteria from dead and moribund fish during outbreaks of rainbow trout, Oncorhynchus mykiss (Walbaum), fry syndrome in England. Journal of Fish Diseases, 14(6): 677-682. https://doi.org/10.1111/j.13652761.1991.tb00626.x

Bernardet, J.P., Kerouault, B. 1989. Phenotypic and genomic studies of 'Cytophaga psychrophila' isolated from diseased rainbow trout (Oncorhynchus mykiss) in France. Applied and Environmental Microbiology, 55(7): 1796-1800.

https://doi.org/10.1128/AEM.55.7.17961800.1989

Beutler, E. 1975. Red cell metabolism. A manual of biochemical methods. New York, NY: Grune \& Stratton. p. 112-114, ISBN 0808908618.

Bustos, P., Calbuyahue, A., Maontaña, J., Opazo, B., Entrala, P., Solervicens, R. 1995. First isolation of Flavobacterium psychrophilum as causative agent of rainbow trout fry syndrome (RTFS) in Chile. Bulletin European Association of Fish Pathologists, 15(5): 162164.

Carlberg, I., Mannervik, B. 1975. Purification and characterization of the flavoenzyme glutathione reductase from rat liver. Journal of Biological Chemistry, 250(14): 54755480.

Cazenave, J., de los Angeles Bistoni, M., Pesce, S. F., Wunderlin, D.A. 2006. Differential detoxification and antioxidant response in diverse organs of Corydoras paleatus experimentally exposed to microcystin-RR. Aquatic Toxicology, 76(1): 1-12.

Cheeseman, K.H., Slater, T.F. 1993. An in production to free radical biochemistry. British Medical Bulletin, 49(3): 481-93.

Dalsgaard, I., Madsen, L. 2000. Bacterial pathogens in rainbow trout Oncorhynchus mykiss (Walbaum), reared at Danish freshwater farms. Journal of Fish Disease, 23(3): 199$209 . \quad$ https://doi.org/10.1046/j.13652761.2000.00242.x
Diler, Ö., Altun, S., Işıklı, B.I. 2003. Kültürü yapılan gökkuşağı alabalıkları (Oncorhynchus mykiss)'ndan izole edilen Flavobacterium psychrophilum'un fenotipik karakterleri. Süleyman Demirel Üniversitesi Fen Bilimleri Enstitüsü Dergisi, 7(1): 1-8.

Downs, C.A., Fauth, J.E., Woodley, C.M. 2001. Assessing the health of grass shrimp (Palaeomonetes pugio) exposed to natural and anthropogenic stressors: a molecular biomarker system. Marine Biotechnology, 3(4):

380-397. https://doi.org/10.1007/s10126-001-00083.

Ekipmen, E., Avcı, H., Tanrıkul, T., Birincioğlu, S., Aydoğan, A. 2020. Flavobacterium psychrophilum ile doğal enfekte gökkuşağı alabalıklarında (Oncorhynchus mykiss) patolojik ve mikrobiyolojik incelemeler. Kocatepe Veterinary Journal, 13(2): 172178. https://doi.org/10.30607/kvj.689521

El-Sayed, G.R., Barakat, L. A., El-Magd, M. A., Hassan, E.A., Awadalla, G. 2019. Impact of Aeromonas hydrophila Infection on oxidative stress in Nile Tilapia. Chemistry Research Journal, 4(4):11-16

Ersoy, A.T., Metin. S., Onuk, E.E. 2018. Akdeniz Bölgesi'ndeki gökkuşağı alabalıklarından izole edilen Flavobacterium psychrophilum suşlarının fenotipik ve genetik farklılıklarının belirlenmesi. Acta Aquatica Turcica, 14(4): 265-275. https://doi.org/10.22392/egirdir.400641

García J.J., Reiter R.J., Guerrero J.M., Escames G., Yu B.P., Oh C.S., Muñoz-Hoyos A. 1997. Melatonin prevents changes in microsomal membrane fluidity during induced lipid peroxidation. FEBS Letters, 408(3), 297-300. https://doi.org/10.1016/s00145793(97)00447-x

Gutierrez, M.A., Miyazaki, T. 1994. Responses of Japanese eels to oral challenge with Edwardsiella tarda after vaccination with formalin-killed cells or lipopolysaccharide of the bacterium. Journal of Aquatic Animal Health, 6(2): 110-117. https://doi.org/10.1577/15488667(1994)006<0110:ROJETO>2.3.CO;2

Halliwell, B. 1994. Free radicals and antioxidants: a personal view. Nutrition reviews, 52(8): 253-265. https://doi.org/10.1111/j.17534887.1994.tb01453.x

Huang, H. Y., Chen, Y. C., Wang, P. C., Tsai, M. A., Yeh, S. C., Liang, H. J., Chen, S. C. 2014. Efficacy of a formalin-inactivated vaccine against Streptococcus iniae infection in the farmed grouper Epinephelus coioides by 
intraperitoneal immunization. Vaccine, 51(32): 7014-7020.

Ispir, U., Gokhan, H. B., Ozcan, M., Dorucu, M., Saglam, N. 2009. Immune Response of Rainbow Trout (Oncorhynchus mykiss) to Selected Antigens of Yersinia ruckeri. Acta Veterinaria Brno, 78(1): 145-150. https://doi.org/10.2754/avb200978010145

İspir, Ü., Şeker, E., Sağlam, N., Dörücü, M. 2004. Doğu Anadolu Bölgesinde bazı gökkuşağı alabalığı (Oncorhynchus mykiss) işletmelerinde Flavobacterium psychrophilum enfeksiyonunun araştırılması. Fırat Üniversitesi Fen Mühendislik Bilimleri Dergisi, 16(4): 718724.

İspir, Ü., Türk, C., Kırıcı, M. 2013. Bingöl'de ticari bir gökkuşağı alabalığı (Oncorhynchus mykiss) çiftliğinde Flavobacterium psycrophilum salgını. Menba Su Ürünleri Fakültesi Dergisi, 1(2): 25-29.

İspir, Ü., Türk, C., Kırıcı, M., Taysı, M.R., Özcan, M. 2016. Gökkuşağı alabalığı (Oncorhynchus mykiss)'nın inaktive Flavobacterium psychrophilum içeren aljinat mikropartikülleri ile immunizasyonu. Ege Journal of Fisheries and Aquatic Sciences, 33(3): 233-240.

Kent, M.L., Groff, J.M., Morrison, J.K., Yasutake, W.T., Holt, R.A. 1989. Spiral swimming behavior due to cranial and vertebral lesions associated with Cytophaga psychrophila infections in salmonid fishes. Diseases of Aquatic Organisms, 6: 11-16.

Kılıç, A., Şeker, E., Özcan, M., İspir Ü. 2007. Elazığ'daki gökkuşağı alabalığı (Oncorhynchus mykiss) işletmelerinin bakteriyel yönden incelenmesi. Fırat Üniversitesi Fen ve Mühendislik Bilimleri Dergisi, 19(2): 129-132.

Kırıcı, M., İspir, Ü., Atamanalp, M. 2014. Efficacy of a formalin-killed vaccine against Flavobacterium psychrophilum in Rainbow Trout (Oncorhynchus mykiss). Turkish Journal of Agricultural and Natural Sciences, 1(2): 215-218.

Lowry, O.H., Rosebrough, N.J., Farr, A.L., Randall, R.J. 1951. Protein measurement with Folin phenol reagent, Journal of Biological Chemistry, 193: 265-275.

Nguyen, H.T., Nguyen, T.T.T., Tsai, M.A., Ya-Zhen, E., Wang, P.C., Chen, S.C. 2017. A formalininactivated vaccine provides good protection against Vibrio harveyi infection in orange-spotted grouper (Epinephelus coioides). Fish and Shellfish Immunology,
65

118-126.

https://doi.org/10.1016/j.fsi.2017.04.008

Önalan, Ş. 2019. Expression differences of stress and immunity genes in rainbow trout (Oncorhynchus mykiss, Walbaum 1792) with different bacterial fish diseases. The Israeli Journal of Aquaculture-Bamidgeh, 71: 1-10.

Önalan, Ş., Çevik, M. 2020. Investigation of the effects of some phytochemicals on Yersinia ruckeri and antimicrobial resistance. Brazilian Journal of Biology, 80: 934-942. http://dx.doi.org/10.1590/15196984.234969

Özcan, M., Sarieyyupoglu, M. 2014. Identification and investigation of phenotypic and genotypic characteristics of Flavobacterium psychrophilum in fry rainbow trouts (Oncorhynchus mykiss) in some trout. International Journal of Sciences, 3(3): 2434.

Özer, S., Demirel, M., Us, M., Yıldırım, S. 2008. Mersin illi Çağlarca Köyü'ndeki gökkuşağı alabalığı (Oncorhynchus mykiss, Walbaum) kuluçkahanelerinin mikrobiyal florası. Journal of Fisheries Sciences.com, 2: 261271.

Pacha, R.E. 1968. Characteristics of Cytophaga psychrophila (Borg) isolated during outbreaks of bacterial cold-water Disease. Applied Microbiology, 16(1): 97-101.

Pan, C.H., Chien, Y.H., Hunter, B. 2003. Alterations of antioxidant capacity and hepatopancreatic enzymes in Penaeus monodon (Fabricius) juveniles fed diets supplemented with astaxanthin and exposed to Vibrio damsela challenge. Journal of the Fisheries Society of Taiwan, 30(4): 279-290.

Placer, Z.A., Cushman, L., Johnson, B.C. 1966. Estimation of products of lipid peroxidation (malonyldialdehyde) in biological fluids. Analytical Biochemistry, 16: 359-364.

Pryor, W.A. 1986. Oxy-radicals and related species: their formation, lifetimes, and reactions. Annual review of Physiology, 48: 657-667.

Pulpipat, T., Maekawa, S., Wang, P. C., Chen, S. C. 2020. Immune responses and protective efficacy of a formalin-killed francisella noatunensis subsp. orientalis vaccine evaluated through intraperitoneal and ımmersion challenge methods in Oreochromis niloticus. Vaccines, 8(2): 163. https://doi.org/10.3390/vaccines8020163

Rahal A., Kumar A., Singh V., Yadav B., Tiwari R., Chakraborty S., Dhama K. 2014. Oxidative stress, prooxidants, and antioxidants: the 
interplay. BioMed Research International, 761264. https://doi.org/10.1155/2014/ 761264.

Santos, Y., Huntly, P.J., Turnbull, A., Hastings, T.S. 1992. Isolation of Cytophaga psychrophila (Flexibacter psychrophllus) in association with rainbow trout mortality in the United Kingdom. Bulletin-European Association of Fish Pathologists, 12: 209-210.

Satıcıoğlu I.B., Duman M., Wiklund T., Altun S. 2018. Serological and genetic characterization of Flavobacterium psychrophilum isolated from farmed salmonids in Turkey. Journal Of Fish Diseases, 41: 1899-1908. https://doi.org/10.1111/jfd.12901

Schimidtke, L.M., Carson, J. 1995. Characteristics of Flexibacter psychrophilus isolated from atlantic salmon in Australia. Diseases of Aquatic Organisms, 21(2) : 157-161.

Sies, H. 1991. Oxidative stress: oxidants and antioxidants. Experimental Physiology, 82: 291- 295.

Sinclair, A.J. 1993. Free radical mechanisms and vascular complications of diabetes mellitus. Diabetes Reviews, 2: 7-10.

Sun, Y., Oberley, L.W., Li, Y. 1988. A simple method for clinical assay of superoxide dismutase. Clinical Chemistry, 34: 497-500.

Şeker, E., Kılıç, A., Özcan, M., İspir, Ü. 2006. Malatya'daki bazı gökkuşağı alabalık (Oncorhynchus mykiss) işletmelerinin bakteriyel florası. Fırat Üniversitesi Doğu Araştırmaları Dergisi, 5: 15-18.

Tkachenko, H., Grudniewska, J., Pękala, A. 2017. Effects of oral vaccinaton against Yersinia ruckeri on oxidative stress biomarkers in gills, liver and heart of rainbow trout (Oncorhynchus mykiss Walbaum). Baltic Coastal Zone, 21: 109-128.

Tkachenko, H., Kurhaluk, N., Grudniewska, J., Andriichuk, A. 2014. Tissue-specific responses of oxidative stress biomarkers and antioxidant defenses in rainbow trout Oncorhynchus mykiss during a vaccination against furunculosis. Fish Physiology and Biochemistry, 40: 1289-1300.

Wakabayashi, H., Horiuchi, M., Bunya, T., Hoshiai, G. 1991. Outbreaks of cold-water disease in coho salmon in Japan. Fish Pathology, 26: 211-212.

Wakabayashi, H., Toyama, T., Lida, T. 1994. A Study on serotyping of Cytophaga psychrophila isolated from fishes in Japan. Fish Pathology, 29: 101-104.

Wiklund, T., Kaas, K., Lönnström, L., Dalsgaard, I. 1994. Isolation of Cytophaga psychrophila (Flexibacter psychrophilus) from wild and farmed rainbow trout (Oncorhynchus mykiss) in Finland. Bulletin European Association of Fish Pathologists, 14: 44-56.

Xia, H., Tang, Y., Lu, F., Luo, Y., Yang, P., Wang, W., Jiang, J., Li, N., Han, Q., Liu, F., Liu, L. 2017. The effect of Aeromonas hydrophila infection on the non-specific immunity of blunt snout bream (Megalobrama amblycephala). Central-European journal of immunology, 42(3): 239-243. https://doi.org/10.5114/ceji.2017.70965

Yang, L., Tan, G., Fu, Y., Feng, J., Zhang, M. 2010. Effects of acute heat stres and subsequent stres removal on function of hepatic mitochondrial respiration, ROS production and lipid peroxidation in broiler chickens. Comparative Biochemistry and Physiology, 151(2): 204-208.

Yıldırım, S., Özer, S. 2010. Mersin ili Çağlarca Köyündeki Gökkuşağı Alabalığı (Oncorhynchus mykiss, Walbaum, 1792) kuluçkahanelerinde Flavobacterium spp. Varlığı. Journal of FisheriesSciences.com, 4: 112-122.

Yonar, S.M. 2013. Toxic effects of malathion in carp, Cyprinus carpio carpio: protective role of lycopene. Ecotoxicology and Environmental Safety, 97, 223-229. https://doi.org/10.1016/j.ecoenv.2013.07.0 20 